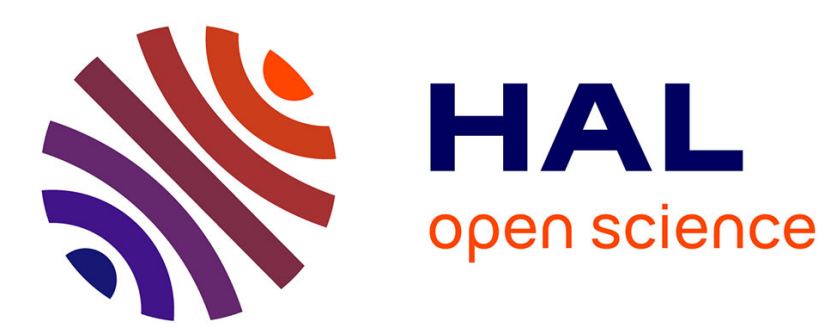

\title{
An organisational design approach of business environments: the case of Barcamps milieu in Paris \\ Paris Chrysos
}

\section{To cite this version:}

Paris Chrysos. An organisational design approach of business environments: the case of Barcamps milieu in Paris. International Journal of Organisational Design and Engineering, 2011, 1 (4/2011), pp.315-330. 10.1504/IJODE.2011.043809 . halshs-00796937

\section{HAL Id: halshs-00796937 \\ https://shs.hal.science/halshs-00796937}

Submitted on 6 Mar 2013

HAL is a multi-disciplinary open access archive for the deposit and dissemination of scientific research documents, whether they are published or not. The documents may come from teaching and research institutions in France or abroad, or from public or private research centers.
L'archive ouverte pluridisciplinaire HAL, est destinée au dépôt et à la diffusion de documents scientifiques de niveau recherche, publiés ou non, émanant des établissements d'enseignement et de recherche français ou étrangers, des laboratoires publics ou privés. 


\title{
An organisational design approach of business environments: the case of Barcamps milieu in Paris
}

\author{
Paris Chrysos \\ Centre for Scientific Management (CGS), \\ Mines-ParisTech, \\ 60 Boulevard Saint-Michel, 75272 Paris, France \\ E-mail: paris.chrysos@ensmp.fr
}

\begin{abstract}
Shifting business environment is often described as a decisive factor for organisational transformations. Various levels of organisation are proposed by the literature in order for an enterprise to be able to handle factors that outreach their boundaries. In this paper, we examine the case of Barcamps, a novel organisational pattern addressing issues beyond productivity and efficiency. We propose an analysis of its design parameters and functional requirements, contributing to the research and practice of organisational design beyond the boundaries of a specific organisation.
\end{abstract}

Keywords: open innovation; start-up; innovation networks; business environments; organisational design.

Reference to this paper should be made as follows: Chrysos, P. (2011) 'An organisational design approach of business environments: the case of Barcamps milieu in Paris', Int. J. Organisational Design and Engineering, Vol. 1, No. 4, pp.315-330.

Biographical notes: Paris Chrysos is a $\mathrm{PhD}$ candidate in the Centre for Scientific Management (CGS), Mines-ParisTech. He obtained his Diploma of Electrical and Computer Engineering at the National Technical University of Athens and his Master of Research (M2) in Sociology of Innovation at the University Paris-Est. His research focuses on tools and methods for innovation management within entrepreneurial ecosystems. His dissertation studies the implications of the Web 2.0 platform design on the development and the organisation of business communities.

\section{Introduction}

Organisation studies in the business domain often face business environment as a shifting factor that determines an enterprises strategical decision. Yet, there is a lack of organisational approaches to the business environment itself, as its complexity renders it difficult to rationalise an activity having this environment as a field, beyond the concept of the market and the commercial relations.

Open innovation is a widely diffused approach that is proposed to reduce the gap between organisation and business environment. Yet, this framework does not provide analytical tools to handle business environment complexity. Between an enterprise and the shifting business environment, literature on management had studied a great variety of organisational forms for innovation, including partnerships, alliances and ecosystems. 
Yet, there is a lack in the literature concerning the design of organisations addressing the business environment or parts of it.

In this paper, we study the case of the emergence of a business milieu in the region of Paris. This milieu allows enterprises and entrepreneurs to actively observe different aspects of a shifting business environment. It was constructed by a series of informal conferences, called Barcamps. Barcamps have been characterised as 'contact-generating machine' forming a 'third place' which is neither the workspace nor the domicile space (Aguiton and Cardon, 2007). Barcamps can be also seen as a mean to actively observe a sample of a business environment.

Each event, during one or two days, is sponsored by different organisations, participation is open to everyone interested and the topics of discussion and experimentation are proposed by the participants themselves.

We are interested in studying the organisation of these events from a design perspective, in order to configure the design patterns of this organisational 'machine'.

Historically, Barcamps began in 2005 in San Francisco, USA, by web entrepreneurs that could not participate to an official conference, the Foocamp, because of its fees as well as of the fact that invitations to the conference were limited. Since then, their format was spread on an international level, and hundreds of Barcamps reassembled platform suppliers, developers/entrepreneurs and 'curious' users, interested in innovation in the context of the ICTs.

We study the particular case of the emergence of Barcamps in the region of Paris. Sixteen events that took place during the period from the 6th of December 2005 to the 5th of April 2008 constitute our study field.

We find that this design can be decomposed in three modules, addressing the need for business environment monitoring and exploring as well as the need for social networking and business ecosystem structuring.

\section{Literature review}

An important area of innovation literature has been recently based around the notion of open innovation, as defined by Chesbrough (2004), Chesbrough et al. (2006), and Chesbrough and Schwartz (2007). This literature focuses particularly on the 'inflows and outflows of ideas and knowledge' and has as its reference the boundaries of a given organisation that is the enterprise which deploys the open innovation activity for its benefit. The broad notion of open innovation has stimulated much discussion within the academic community concerning whether it is "a field of study or a communication barrier to theory development" (e.g., von Hippel, 2010; von Krogh, 2011). Still, a central question remains open: do the boundaries of a given organisation constitute the appropriate level of analysis for every innovation process?

In management studies one can find a broad spectrum of organisation modes for innovation, beyond the level of a single enterprise. Teece and Chesbrough (2002) summarised five typical models of business organisation for innovation: virtual organisation (Alexander, 1997; Wiggins and Crowston, 2010), alliances (Osborn and Hagedoorn, 1997; Soh, 2009), joint venture (Inkpen and Beamish, 1997; 
Peng and Shenkar, 2002), corporation with autonomous divisions and integrated corporation (March and Simon, 1958; Henderson and Clark, 1990; Nakhla, 2003). More recently, research in new product development has focussed on the case of co-development (Chesbrough and Schwartz, 2007; Maniak and Midler, 2008) as well as exploration (Segrestin, 2005; Gillier et al., 2010) partnerships. In research fields where the organisational mode includes multiple firms, a central issue (for both practitioners and academics) is the definition of the common boundaries (of the alliance, the venture or the partnership). On the other hand, when innovation is studied at the level of a single firm, the focus of the analysis is on the boundaries between different departments. Moreover, the more exploratory the nature of a project, the more difficult it becomes for the actors to evaluate and share the results of eventual innovations.

Furthermore, Chesbrough et al. (2006) go beyond the structure of a single enterprise or enterprise partnerships, to the notion of the ecosystem. For this, Chesbrough uses the theory of social networks (Granovetter, 1973, 1983) to interpret inter-organisational relations. According to Granovetter, individuals being in the centre of social networks can benefit from the diffusion of innovations, either initiated by others or by themselves. Another approach on ecosystems is the one of platform leadership (Gawer and Cusumano, 2002), where different platforms compete on obtaining a dominant place in a given business domain. Yet, both approaches mentioned, pre-suppose that an ecosystem already exists, either in the form of weak social ties, or in the form of a technical infrastructure of reference.

Drawing from the science of biology, Moore (1993) proposed four phases of life for business ecosystems:

1 birth

2 expansion

3 leadership

4 self-renewal.

According to Moore, "managers can design longevity in an ecosystem", while "an altered environment is often more hospitable to new or formerly marginal business ecosystems". Different ecosystems compete in a shifting business environment. In this perspective, research has focussed on the design of such ecosystems, on the basis of a technology of a specific enterprise (e.g., Kraemer and Dedrick, 2002; Isckia, 2009).

In parallel, the experience of web networks and communities revealed an important research field for novel organisational designs (Benkler, 2006; Gensollen, 2007; Stieglitz and Lattemann, 2008).

From the above, we see that the levels of analysis answering to the question 'how to organise for innovation', vary from the level of social networks amongst individuals, to structured organisations, partnerships and beyond, to competing industries and ecosystems within a global business environment (see Figure 1). Yet, the business environment remains a factor of uncertainty, where innovation process is not only "unknown, it is unknowable" (Chesbrough, 2004), pushing to intensive innovation (Le Masson et al., 2010). 
Figure 1 Graphical representation of the following organisational 'sets': department $\subset$ organisation $\subset$ partnership $\subset$ industry $\subset$ business ecosystem $\subset$ business environment

BUSINESS ENVIRONMENT

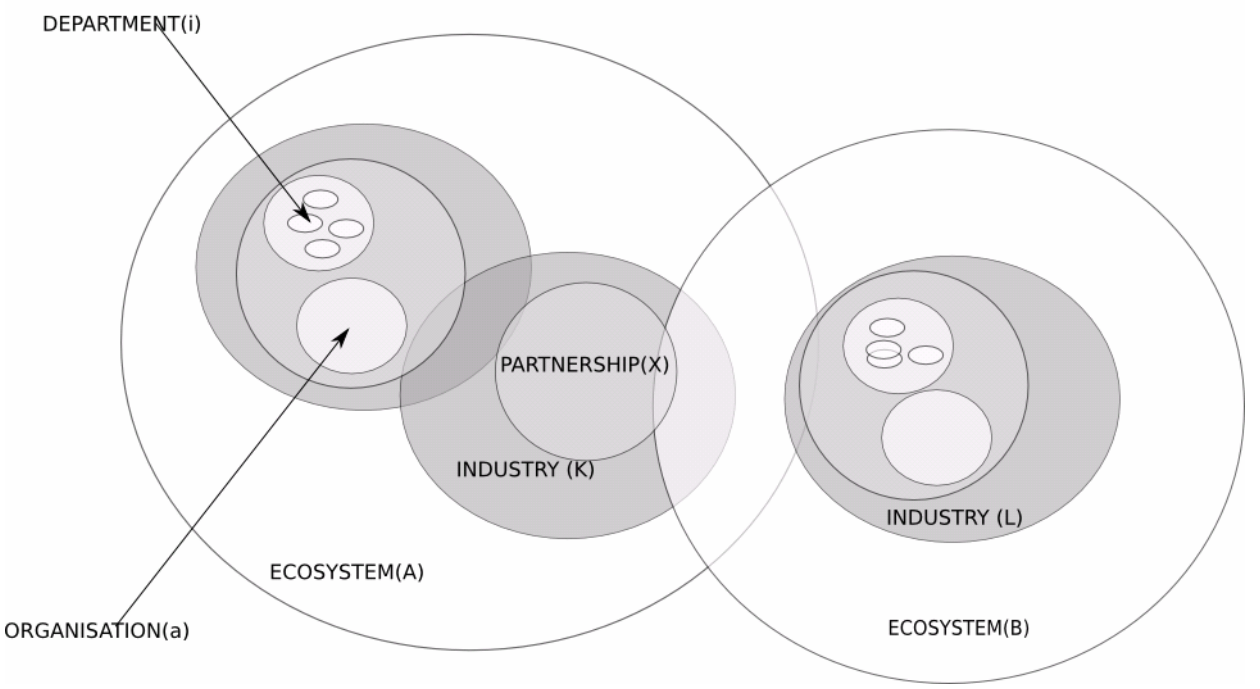

Consequently, a question arises: can a business environment be designed? What could organisational design for a business environment mean? Are the design parameters (DPs) used in lower levels (such as labour division, task division and knowledge division) still sufficient in that case?

To respond to these questions, we study a particular case of innovation environment the case of the Barcamp events, organised in the region of Paris, France. These informal events constitute a meeting point of various ecosystems, using different technological platforms as well as an organisational tool for the active observation of a shifting business environment.

\section{Research methodology}

We are examining 16 events that took place within the period from the 6th of December 2005 to the 5th of April 2008. To analyse this emerging environment, we used two different research methods:

1 Participatory observation of the events. To enable us have a concrete view of Barcamp's process, we participated in eight of the 16 events organised in Paris. We took part in the discussions and made numerous conversations with the participants during the events, taking notes on the process.

2 Data sourcing, data processing and data analysis. Either available online, either produced by us, or provided to us by participants and organisers, the data we use in this paper are of two types: 
a Quantity data: Data concerning the amount of participation in Barcamps (per event and per participant) as well as the organisational origin of the participants. The main source of this data was the registration files. A complex computer data processing was necessary to render these data - existing in various formats - in an exploitable form.

b Quality data: Videos, photos, descriptions of the events, software applications were examined. An analytical study of this kind of data produced by participants (often characterised by personal, cultural and professional approaches) was necessary.

Our research methodology follows a design approach based on the theory of axiomatic design (Suh, 1990; Kim et al., 1991), adopted to the level of business environment design. Suh's theory, originally conceived to enable an a posteriori design evaluation, permits the analysis of a given technology by configuring the DPS in relation to the functional requirements (FRs) of its design. The DPs are understood as the answers to the question 'how?', or the inputs to a specific system, while the FRs are understood as the answers to the question 'what?', or the outputs of the system. For this adoption, we take into consideration the descriptive model on group behaviour and effectiveness (Hackman, 1987). Hackman's model studies organisational processes also by examining the inputs and the outputs of a work group design. Yet, in our case the latter model cannot be accurately followed either, as our field does not concern a workspace.

Regarding the DPs, we are going to configure the organisational 'patterns' that characterise all the events and remain relatively stable while participants as well as the topics of the events change. For this, we will base our analysis on the following qualitative material: participatory observation (at eight of the events), documents, photos and videos published by the participants themselves before and after each event.

Regarding the FRs, we are going to configure the 'output' of these events that is the business milieu that was created. For this, we used quantity data coming from the event registration files, available online. The goal of their use is to draw conclusions on the participation modalities in the overall environment, concerning the degree of engagement of individuals in this milieu, as well as the configuration of the 'core' participants and their characteristics.

\section{Field material and analysis}

\subsection{Event topic}

The title of each event is often wide, while sometimes there is no title other than 'Barcamp'. They usually take place in different places and address different issues. An event is typically sponsored by an organisation that accommodates it in its local offices. A specific topic is frequently assumed, indicating a new innovation area where a business ecosystem is expected to emerge. For instance, in the case of the Barcamp organised in Google's local offices in Paris, its title was 'Barcamp Paris 7'. Yet, the discussions were strongly influenced by the launch of the new platform, Google Maps. In a similar way, the event organised in Yahoo's local offices ('Barcamp Paris 11'), was oriented towards the general topic of 'virtual identity', an issue that Yahoo, as well as most web services, was discussing internally by the time when social network platforms arose. 
In our field, the more events were organised, the more specific the title became, remaining though wide. That is the case of the event sponsored by SUN Microsystems which was entitled 'Tools 2.0' - that is tools for Web 2.0 services. These tools are more often developed by programmers using Java or AJAX, programming languages animated by SUN Microsystems. An event can be sponsored by multiple organisations (corporations, start-ups or institutes) and no authorisation is needed for its organisation.

Compared to the organisational forms met on the web, the construction of networks around a wide topic is a general characteristic of online interaction (Chakrabarti et al., 2002; Highfield et al., 2010).

At this point, there is a 'common particularity', shared between the milieu we study and online interaction. They are both situated in between social networks (described as connections between individuals) and communities (described as social groups sharing common interests and practices), as they are built around general interests expressed by their topic.

Seen as an organisational DP, the fact that an event has a wide topic satisfies the requirement of attracting individuals 'belonging' - by their interests - to the general business environment to be monitored and explored.

\subsection{Registration process}

The diffusion of the information about the organisation of an event passes through informal networks of entrepreneurs and communities and not through traditional media. In the case of Paris, the mailing list of Silicon Sentier, an association of ICT start-ups, was one of the main information diffusion means.

Registration to the events is open to everyone. Through a web page dedicated to each event, everyone interested can self-register, submitting his/her name, personal web page, organisation and e-mail to a list. There is no secretary for the events and no authorisation is needed in order to register or to organise an event. All these event pages are hosted in a common portal (http://www.barcamp.org).

The only limit to participation is posed by the capacity of the building. The list of participants is completed publicly until their number reaches the threshold of that capacity.

Open participation is also a principle widely followed in web communities, such as Wikipedia or online fora, where everyone is able to contribute without authorisation.

The DP of registration process openness satisfies the requirement of 'outsiders' participation. Each event is open to actors that does not usually take part in known ecosystems or networks. Their presence gives the opportunity to extend one's network beyond a specific industry, as well as to obtain new information and knowledge from other, neighbour fields.

\subsection{Self-presentation}

The day of the event, participants gather at the programmed place and time. The procedure begins by their self-presentation. Each one uses three tags to describe himself, along with his name and profession. For instance, in the Barcamp organised in the local office of Google in Paris, a participant introduced herself using the tags 'innovation', 'interdependence' and 'chocolate'. This kind of introduction drives to the self-classification of the individuals according to their expertise or interests and 
facilitates social interaction and networking on the basis of specific projects during the event. In the same event, one could meet amongst the participants the product manager of Gmail and Google Maps, the founder of the Netvibes web service, the president of APRIL (French association for the promotion of free software), and a researcher from the San Francisco France Telecom R\&D Department.

Even if the most important part of the participants was coming from the computer science discipline, many also came from different disciplines: management, finance, sociology, psychology. Amongst the registered persons, one could find ten persons coming from Google, seven coming from France Telecom R\&D (Orange Labs), four from SFR telecommunication company, as well as many entrepreneurs of Silicon Sentier association, members of the foundation internet new generation (FING), and executives of firms like Mandriva-Linux, Hewlett Packard, SEGA and SUN Microsystems.

As an organisational DP, the 'self-tagging' borrows the practice of 'folksonomy' met in web services that host user-generated content. In the case of the absence of a typical taxonomy, web users classify content using tags to characterise it (Auray, 2007). Yet, instead of characterising content, participants in our case characterise themselves. At the end of the presentation everyone can have a global vision of the identities of the participants to which he has the opportunity network and share information, according to their skills, organisation or interests.

\subsection{Programme definition}

After the presentations, participants define the subjects of the discussion themselves. For this purpose, a whiteboard is already prepared by the organisers, where the rooms and the time slots of the discussions are already completed, waiting for the subjects to be filled in.

Barcamp Paris 11 took place at Yahoo's local offices and was co-sponsored by Silicon Sentier, Ziki (a web market putting in contact different enterprises) and Passage Piétons (an event organising agency). After the self-presentation of the participants, they were invited to fill a whiteboard with the discussion topics they desired. On the table there were already marked the names of the available rooms (Montorgueil, Barbès, Rue de la Paix, Lepic, Trocadero, Beaubourg, Grande Arche, Montmartre) in columns and the names of the available time slots $(15: 30,16: 30$, break, 18:00, 19:00) in rows. As the centre of the common reflection was the concept of virtual identity, various relative discussion themes were proposed and they either were merged in the same discussion group or constituted a different one. Discussions on digital identity included the following: Digital identity by art: the project Skatcha'rt, Being and appearance Twitter $+R S S+$ Blog $=$ Communication = identity for a lifetime, as of last week where and how to define the Being, Todeka project digital identity certification. Yet, there were also discussion topics not included in the thematology of digital identity, such as coworking Paris and website, Netvibes $U W A^{1}$ and widgets: widgets engines, widgetisation of the web.

This division of the participating 'crowd' in many thematic discussions, serves in having more concrete and specific discussion groups, according to their own interests. This way an exploration of the environment which is a much more focussed becomes possible, during which useful knowledge and concepts can emerge and be shared.

From the networking perspective, discussion in small, interest oriented groups reinforces the capabilities to expend one's network, as well as the scope of exploration. 
These discussions are very useful for small enterprises allowing them to trace the important evolutions of their field as well as to present their projects and skills to eventual clients or partners. For platform providers, it gives a chance to spot the future innovation trajectories and use this feedback to adjust aspects of their platforms.

In addition, Barcamps constitute an environment permitting close interaction between different business ecosystems (as for the ecosystem of Yahoo developers and the one of Netvibes developers in the Barcamp Paris 11 case) taking part in the same business environment.

\subsection{Collective experimentation and creative learning}

After the talks, an experimentation process, called Mashpit usually takes place using the concepts and knowledge that emerged during the discussions. During a Mashpit participants create prototypes of new applications and services. A Mashpit can often be a multidisciplinary process, as individuals coming from other disciplines that the one of computer programming (such as design, marketing or social sciences) can also participate.

In the case of the event organised in Google's local offices, a Mashpit took place during the second day, where 48 individuals were registered and where ten projects were proposed on the basis of Google Maps. ${ }^{2}$ When participants met, they voted for three out of the ten projects to be developed. After a coffee break, they were divided in three project groups and started working. Finally, each team presented its project.

We are going to present here one of the three innovative projects. It is called interactive map. This application had a very simple functionality: the user could mark points on a map of Paris by a single click. Beginning from the first marked point, a path was automatically created to the next points marked. Finally, a course was designed by the user in some clicks. He could execute the application as many times he wanted to design more courses on the map. In the site of the project there was no indication of specific uses of this prototype. Nevertheless, we can imagine a way in which this application could be used for a new web service: a site where tourist guides, before exiting the hotel with their clients for a walk in Paris, can demonstrate the course that will be followed.

Nevertheless, whether or not the prototype will end up being a commercialised service or application is not critical (today one can find applications and features of Google Maps lot more sophisticated than the 'interactive map'). What is important, for both developers/entrepreneurs and platform providers, is to experiment on the innovation potential of a new platform (as well as of a combination of already existing platforms), check the functionalities and documentation provided and, eventually, expand the platform via the entrepreneurial activity after the event by adopting each tools.

\subsection{Resulting milieu}

In this section, we are interested in examining the output of the entire process of the events, as expressed by the specific structure of a particular environment. Following a quantitative methodology, we configure the qualitative characteristics of participation in the whole environment as well as the specific characteristics of the 'core' of this milieu, focussing on the last latter. 


\subsubsection{Milieu as a whole}

From the elaboration of the registration files to 16 Barcamps organised in Paris, we found that 713 individuals were registered in these events. $3 \%$ of this population has been registered for more than six times, $10 \%$ has participated from three to six times, while $87 \%$ has participated only once or twice.

While participants came from different professional environments, there were two categories that actively formed this milieu: developers/entrepreneurs of information and communication technologies start-ups or small enterprises from the one hand, and executives of platform providers, usually in charge of technology or community affairs, from the other hand.

What the participation rates prove is that this milieu managed to be very open, attracting individuals that were interested in specific 'wide' topics. Surprisingly, this participation rates are similar to the ones observed in online communities (Benkler, 2006; Stieglitz and Lattemann, 2008). For instance, in the case of Wikipedia, where participation also does not require authorisation, the percentage of very active contributors is $4 \%$, the percentage of active contributors $25 \%$, while $71 \%$ contributes more less.

\subsubsection{Core of the milieu}

As Barcamps are informal events, many of which were organised by 'ad hoc' sponsors, the participation rate was our criterion to configure the most active group of participants. Another way to configure the organising core of these events could just be to list the sponsors of all the events (presented in the Table 1). Nevertheless, since Barcamps are 'ad hoc' events, this method could lead as to false conclusions, as the sponsors of the events are not engaged on the animation of future ones. Measuring the actual participation of individuals is proposed to be a more solid method in order to configure the organising core of these events. Once the most active individuals were identified, we proceeded in configuring the organisations to which these individuals belong. This was mainly concluded on the basis of the organisation they declared in the registration phase. Complementary data provided to us by the organisers were also used. Finally, we produced the schema shown in the Figure 2.

In Figure 2, we see a representation of the core of the Barcamps milieu in Paris, during the examined period, consisted by the most active participants. Each participant is represented by the letter $\mathrm{A}$ and a number $(i=1 \ldots 23)$. Each group is represented by an ellipse. As there are no axes in this schema, the size or the orientation of the ellipses is irrelevant.

The first remark we can make is that the core of Barcamps in Paris is much structured. The great majority of people actually animating the Barcamps is acting along with group colleagues of theirs. Only six out of 23 persons were being very active in Barcamps without being accompanied at this intense activity by a colleague of theirs. Another fact that we can easily observe, is that the co-working network plays a central role in the constitution of this core, as it connects like a 'bridge' (Granovetter, 1973) all the participating groups (at least one individual of each group is inside the co-working ellipse). The ellipse of co-working is left open, as it is an international network 'passing through' many other cities. 
Table 1 The 16 Barcamps that took place in Paris during the examined period (data extracted from registration files)

\begin{tabular}{|c|c|c|c|c|c|}
\hline $\begin{array}{l}\text { Barcamp } \\
\text { no. }\end{array}$ & Place & Subject & Registrations & Sponsors & Duration \\
\hline 1 & Café DUNE & $\begin{array}{l}\text { How to } \\
\text { organise a 'real } \\
\text { Barcamp' }\end{array}$ & 7 & - & $7 \mathrm{~h}$ \\
\hline 2 & Silicon Sentier & $\begin{array}{l}\text { No specific } \\
\text { subject }\end{array}$ & 74 & $\begin{array}{l}\text { Bearstech, Domaine } \\
\text { Hervé Roumier }\end{array}$ & $\begin{array}{c}7 \mathrm{~h} \\
30 \mathrm{~min}\end{array}$ \\
\hline 3 & Silicon Valois & $\begin{array}{l}\text { Media and } \\
\text { proximity }\end{array}$ & 26 & IGenerator, ViaBloga & $17 \mathrm{~h}$ \\
\hline 4 & Mandriva & $\begin{array}{l}\text { No specific } \\
\text { subject }\end{array}$ & 105 & $\begin{array}{l}\text { Mandriva, AF83, FT } \\
\text { R\&D, Silicon Sentier }\end{array}$ & $7 \mathrm{~h}$ \\
\hline 5 & & & Cancelled & & \\
\hline 6 & $\begin{array}{c}\text { Hôtel } \\
\text { Warwick }\end{array}$ & $\begin{array}{l}\text { Rich internet } \\
\text { APIs }\end{array}$ & 26 & People in Action, Adobe & $3 \mathrm{~h}$ \\
\hline 7 & Google & $\begin{array}{l}\text { No specific } \\
\text { subject }\end{array}$ & 144 & $\begin{array}{l}\text { Google, AF83, Silicon } \\
\text { Sentier, FT R\&D }\end{array}$ & $12 \mathrm{~h}$ \\
\hline 8 & CUBE & $\begin{array}{l}\text { No specific } \\
\text { subject }\end{array}$ & 40 & $\begin{array}{c}\text { Cube, AF83, Silicon } \\
\text { Sentier, FT R\&D }\end{array}$ & $\begin{array}{c}6 \mathrm{~h} \\
30 \mathrm{~min}\end{array}$ \\
\hline 9 & Silicon Valois & $\begin{array}{l}\text { Media and } \\
\text { proximity }\end{array}$ & 9 & $\begin{array}{c}\text { UbiConseil, Explorateurs } \\
\text { du Web }\end{array}$ & $8 \mathrm{~h}$ \\
\hline 10 & DUNE & $\begin{array}{l}\text { Co-working } \\
\text { Paris or «La } \\
\text { Cantine» }\end{array}$ & 18 & - & $2 \mathrm{~h}$ \\
\hline 11 & Yahoo & $\begin{array}{l}\text { No specific } \\
\text { subject }\end{array}$ & 151 & $\begin{array}{c}\text { Yahoo, Ziki, Silicon } \\
\text { Sentier, Passage Piéton }\end{array}$ & $8 \mathrm{~h}$ \\
\hline 12 & $\begin{array}{l}\text { Fondation } \\
\text { Maison des } \\
\text { sciences de } \\
\text { l'homme }\end{array}$ & $\begin{array}{l}\text { Migrating } \\
\text { population and } \\
\text { technology }\end{array}$ & 116 & FMSH, Silicon Sentier & $\begin{array}{c}9 \mathrm{~h} \\
30 \mathrm{~min}\end{array}$ \\
\hline 13 & $\begin{array}{l}\text { O’Sullivans } \\
\text { Bar }\end{array}$ & Second life & 27 & $\begin{array}{l}\text { Community Chest, } \\
\text { O'Sullivans by the Mill, } \\
\text { FON }\end{array}$ & $6 \mathrm{~h}$ \\
\hline Fing & ENSCI & $\begin{array}{l}\text { Projects in } \\
\text { process and } \\
\text { coming } \\
\text { projects in } \\
\text { FING }\end{array}$ & 146 & $\begin{array}{c}\text { Ecole nationale } \\
\text { supérieure de création } \\
\text { industrielle, FING }\end{array}$ & $7 \mathrm{~h}$ \\
\hline 15 & $\begin{array}{c}\text { Sun } \\
\text { Microsystems }\end{array}$ & Tools 2.0 & 155 & $\begin{array}{c}\text { Sun Microsystems, } \\
\text { Silicon Sentier, } \\
\text { OSSGTP, Ruby France, } \\
\text { Supinfo }\end{array}$ & $\begin{array}{c}12 \mathrm{~h} \\
30 \mathrm{~min}\end{array}$ \\
\hline 16 & La Cantine & $\begin{array}{l}\text { No specific } \\
\text { subject }\end{array}$ & 73 & Silicon Sentier & $6 \mathrm{~h}$ \\
\hline Video & La Cantine & Video & 122 & $\begin{array}{c}\text { QuartierNumérique.tv, } \\
\text { SiliconSentier,Quartier } \\
\text { Numerique, faberNovel, } \\
\text { Orange, France24 }\end{array}$ & $6 \mathrm{~h}$ \\
\hline
\end{tabular}


Figure 2 Graphical representation of the 'core' of the milieu

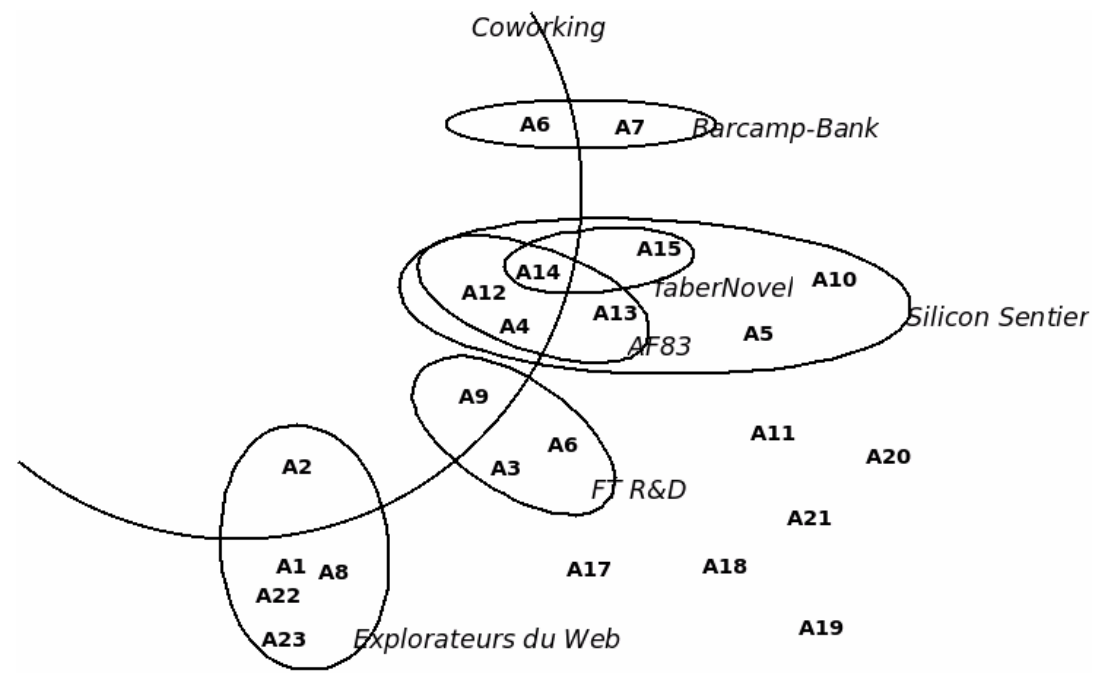

As it came out from the discussions with the actors, collaboration amongst participants beyond this milieu constitutes an eventuality but not a certainty. Both in the core and the periphery, actors are correlated but not necessarily connected.

\subsubsection{Groups of the core}

Co-working is an international network-like community, united in the basis of construction of informal collaboration spaces, where entrepreneurs can meet, work and exchange ideas as well as social niches. During the examined period this network had 734 members on an international level (measured on September 2006). As we see in the Figure 2, six members of the core of Barcamps participate in this network, representing (formally or informally) their group in this network.

This network assures an international connection of these events. International links are particularly valuable for SMEs (and especially ICT SMEs) as an asset for addressing a challenge that has been already remarked (Levy et al., 2003), to open up to a global market, while having local collaborations.

In fact, from the core analysis we see SMEs being more active in the animation of the events. The start-ups association Silicon Sentier had the most important participation in this core. Seven members of Silicon Sentier (A4, A5, A10, A12, A13, A14 and A15) and two start-ups (AF83 and Fabernovel) were animating Barcamps. Silicon Sentier is an association of a hundred new technologies start-ups, active in Paris and supported by the City of Paris. In the last part of the period examined, the association managed to extend its network of members and construct a permanent entrepreneurial milieu (called $\mathrm{La}$ Cantine), where it organises a great variety of events (from Barcamps to seminars and other meetings).

AF83 and Fabernovel followed an important development during the period 2006 (when they were founded) and 2009 following this strategy. Fabernovel is an innovation management consulting company, which managed to multiply by four its turnover during this period. AF83 is an enterprise co-founded and co-animated by Fabernovel and Bearstech (a technology start-up) for the 'agile development' of web applications and 
services as well as for communities animation. For the same period, Bearstech multiplied its turnover by 4.5 .

France Telecom $R \& D$ was also participating in the core of Barcamps in Paris, with three individuals (A9, A3 and A6) participating in the core of Barcamps and one in the Co-working Network. France Telecom (named Orange in between) is the largest telecommunication firm of France. Since its employs more than 3,700 researchers, the participation in this milieu could not be understood as a major environment monitoring and exploring strategy. Yet, it managed to establish a relation with developers/entrepreneurs useful during the launch of its platform, 'Orange Partner', in 2008. That platform allowed SMEs to build upon the company's network, in a way similar to the ecosystems of web platforms.

'Les explorateurs du web' ('web explorers') is a consulting group, created in the Barcamp process, specialised in web services and web applications. Five members of this group (A1, A2, A8, A22 and A23) are taking part in the core of Barcamps in Paris. Beyond its participation to this milieu, this group also organised events ('Explorcamps') that borrow DPs from the Barcamp design while modifying others (for instance, participation is charged for professional events).

Barcamp Bank is another group which emerged in the Barcamp process. Having also international links, this group organised events that aim to link financial investment with entrepreneurs' projects. Two members of this group (A6 and A7) are participating in the core of the milieu in Paris.

After the examined period, different event formats emerged modifying Barcamp's DPs, such as events within large organisations or with topics that were not related at all to ICTs. In addition, the founding of a permanent 'co-working' space by Silicon Sentier intensified the activity of this entrepreneurial milieu beyond the organisation of Barcamps.

\section{Findings}

\subsection{On the nature of a business milieu}

There are two dominant theoretical approaches to analyse social interaction when leaving the boundaries of a specific organisation: networks, as described from Granovetter and utilised by Chesbrough, and communities, following different definitions according to the literature (see for instance, West and Lakhani, 2008). While these two notions are often used in order to analyse similar fields, there are distinct characteristics between them: while the notion of social networks focusses on the nature and strength of existing ties between individuals, the notion of communities focusses on common practices, interests and knowledge, without emphasising the quality of the ties. For instance, research on communities of practice (Wenger, 2007) considers ties between the members of the community to be strong while research on online communities (Gensollen, 2007) proposes that the ties between their members are 'ephemeral' and 'narrow'.

Our research indicates that a milieu, and in particularly a business milieu, is a notion apart. It is a place where networks can be developed or extended whilst meeting with specific communities. As shown from the participation rates, one cannot define the 'boundaries' of this specific organisational form as most individuals participate once or twice whilst participation remains open. 
This 'third place' can be characterised as a place of intimacy. As the historian Habermas (1991) mentions, the notion of the 'intimate places' has appeared during the 18 th century, particularly so during the industrial revolution, defining the sphere in which scientists, philosophers, engineers and entrepreneurs met in a regular but informal way. In the French case, the 'salons de the' were key places were this sphere was developed. Intimate sphere was in interaction with the private, the public and the commercial spheres, constituting a 'melting pot' of knowledge and ideas. Thus, as Habermas notes, parts of it were either absorbed or limited by the private sphere (the case of the domestic 'living room' becoming a 'salon'), the emergence of large industries (organising the social sphere even beyond work) and the dominant role of media in the public sphere.

Using a completely different framework, Barcamps have constructed a milieu that be described by DPs addressing organisations positioned beyond intimate sphere, as interaction is not following the rules of work or of the private life, being at the same time at distance from media-covered events.

\subsection{On the design of a business milieus}

Unlike the typical design of an organisation, we found that an active observation of a shifting environment can be operated by following novel organisational designs. The format of Barcamps, which borrows elements from the design of web communities, can be described from two categories of DPs: open and self-restrictive. By open DPs we refer to the wide topic as well as the open registration parameters, while by self-restricting DPs we refer to the self-presentation, the topic/group partitioning and the experimentation parameters. The FRs of these events are not the same with a typical organisation either. We could describe the FRs of this format as the need to monitor a business environment, attract outsiders, explore the environment, enable creative learning and enable networking.

Making the synthesis of the analysis that preceded, we propose the following DP-FR shown in the Table 2.

Table 2 Organisational DPs - FRs matrix

\begin{tabular}{|c|c|c|c|c|c|c|}
\hline & & \multicolumn{5}{|c|}{ Design parameters $(D P s)$} \\
\hline & & \multicolumn{2}{|r|}{ Open } & \multicolumn{3}{|c|}{ Self-restrictive } \\
\hline & & $\begin{array}{l}\text { Wide } \\
\text { topic }\end{array}$ & $\begin{array}{c}\text { Open } \\
\text { registration }\end{array}$ & $\begin{array}{c}\text { Self- } \\
\text { presentation }\end{array}$ & $\begin{array}{l}\text { Topic/group } \\
\text { partitioning }\end{array}$ & Experimentation \\
\hline \multirow{5}{*}{$\begin{array}{l}\text { Functional } \\
\text { requirement } \\
\text { (FRs) }\end{array}$} & $\begin{array}{l}\text { Monitor } \\
\text { environment }\end{array}$ & $\mathrm{X}$ & $\mathrm{X}$ & & & \\
\hline & $\begin{array}{l}\text { Attract } \\
\text { 'outsiders' }\end{array}$ & $\mathrm{X}$ & $\mathrm{X}$ & & & \\
\hline & $\begin{array}{l}\text { Explore } \\
\text { environment' }\end{array}$ & $\mathrm{X}$ & $\mathrm{X}$ & & $\mathrm{X}$ & $\mathrm{X}$ \\
\hline & $\begin{array}{l}\text { Creative } \\
\text { learning' }\end{array}$ & & & & $\mathrm{X}$ & $\mathrm{X}$ \\
\hline & $\begin{array}{l}\text { Enable } \\
\text { networking }\end{array}$ & $\mathrm{X}$ & $\mathrm{X}$ & $\mathrm{X}$ & $\mathrm{X}$ & $\mathrm{X}$ \\
\hline
\end{tabular}

Following the synthesis proposed, we can identify three distinct modules in the analysed format: 
1 The open invitation module (on the upper-left side of the matrix). This module uses the open DPs and aims to the attraction of a representative sample of a wide business environment. The definition of a wide topic and an open registration process address the requirement of outsiders attraction in order to monitor and explore shifts on a given business environment.

2 The focus module (on the down-right side of the matrix). This module uses the self-restrictive DPs allowing the focus on specialised topics and working groups, enabling a deeper exploration of practices, knowledge and concepts related to existing or emerging business ecosystems.

3 The networking module (on the bottom of the matrix). This module which traverses all DPs, enables social networking by providing the possibility for participants to identify people and topics related to their own interests and extend their (personal or organisational) social network.

This design is the most beneficial for SMEs, as it provides a fast and cheap way to represent the business environment in which they act (first module). In addition, they are in position to acquire more specialise knowledge on their field from neighbour actors and test new tools and practices while exploring innovative concept (second module). Finally, they are able to identify the existing actors, networks and communities at a local level and deploy a networking strategy, including potential partners and clients (third module).

For platform suppliers, such as Google or Yahoo, this design contributes in taking a fast feedback on innovation trajectories that are deployed by entrepreneurs as well as on the documentation and the use modalities of the tools they provide (second module). In addition, as they are able to 'meet in person' a sample of their external developers communities and they are facilitated to extend and structure their ecosystem on a local level (third module), taking into the account the specificities of the local market.

At the same time, these events are catalysed by the presence of 'outsiders', using specific technologies at an amateur or occasional level, usually making 'surprising' remarks that may open new application fields.

\section{Summary}

Beyond objectives such as efficiency and productivity and DPs such as labour division and task division and organisational design can also have objectives such as business environment monitoring and creative learning and utilise parameters such as the definition of wide discussion topics or the self-definition of experimentation processes by participants themselves. Our study on the emergence of an 'intimate' business milieu leads to the proposal of three organisational design modules that allow an active observation of a shifting business environment.

This result can enable further research either towards the examination of our propositions by statistical means or towards the qualitative extension of our analytical framework that could include the correlation with workspace organisations. 


\section{References}

Aguiton, C. and Cardon, D. (2007) 'The strength of weak cooperation: an attempt to understand the meaning of Web 2.0', Communications \& Strategies, Vol. 65, No. 1, pp.51-65.

Alexander, M. (1997) 'Getting to grips with the virtual organization', Long Range Planning, Vol. 30, No. 1, pp.122-124.

Auray, N. (2007) 'Folksonomy: the new way to serendipity', Communications and Strategies, Vol. 65 , No. 1, pp.67-89.

Benkler, Y. (2006) The Wealth of Networks: How Social Production Transforms Markets and Freedom, Yale University Press, New Haven.

Chakrabarti, S., Joshi, M.M., Punera, K. and Pennock, D.M. (2002) 'The structure of broad topics on the web', Proceedings of the Eleventh International Conference on World Wide $W e b-W W W$ '02, p.251, Honolulu, Hawaii, USA.

Chesbrough, H. (2004) 'Managing open innovation', Research-Technology Management, Vol. 47, No, 1, pp.23-26.

Chesbrough, H. and Schwartz, K. (2007) 'Innovating business models with co-development partnerships', Research-Technology Management, Vol. 50, No. 1, pp.55-59.

Chesbrough, H.W., Vanhaverbeke, W. and West, J. (2006) Open Innovation: Researching a New Paradigm, Oxford University Press, Oxford, UK.

Gawer, A. and Cusumano, M.A. (2002) Platform Leadership: How Intel, Microsoft, and Cisco Drive Industry Innovation, Harvard Business Press, Boston, MA.

Gensollen, M. (2007) 'Information goods and online communities', Internet and Digital Economics, pp.173-200, Cambridge University Press, Cambridge, UK; New York.

Gillier, T., Piat, G., Roussel, B. and Truchot, P. (2010) 'Managing innovation fields in a cross-industry exploratory partnership with C-K design theory', Journal of Product Innovation Management, Vol. 27, No. 6, pp.883-896.

Granovetter, M. (1983) 'The strength of weak ties: a network theory revisited', Sociological Theory, Vol. 1, No. 1, pp.201-233.

Granovetter, M.S. (1973) 'The strength of weak ties', The American Journal of Sociology, Vol. 78, No. 6, pp.1360-1380.

Habermas, J. (1991) The Structural Transformation of the Public Sphere: An Inquiry into a Category of Bourgeois Society, MIT Press, Cambridge, Mass.

Hackman, J.R. (1987) 'The design of work teams', in J. Lorsch (Ed.): Handbook of Organizational Behavior, pp.315-342, Prentice-Hall, Englewood Cliffs, NJ.

Henderson, R.M. and Clark, K.B. (1990) 'Architectural innovation: the reconfiguration of existing product technologies and the failure of established firms', Administrative Science Quarterly, Vol. 35, No. 1, pp.9-30.

Highfield, T., Kirchhoff, L. and Nicolai, T. (2010) 'Challenges of tracking topical discussion networks online', Social Science Computer Review, Published online before print 21 September, doi: 10.1177/0894439310382514.

Inkpen, A.C. and Beamish, P.W. (1997) 'Knowledge, bargaining power, and the instability of international joint ventures', The Academy of Management Review, Vol. 22, No. 1, pp.177-202.

Isckia, T. (2009) 'Amazon's evolving ecosystem: a cyber-bookstore and application service provider', Canadian Journal of Administrative Sciences, Vol. 26, No. 4, pp.332-343.

Kim, S., Suh, N.P. and Kim, S. (1991) 'Design of software systems based on axiomatic design', Robotics and Computer-Integrated Manufacturing, Vol. 8, No. 4, pp.243-255.

Kraemer, K.L. and Dedrick, J. (2002) 'Strategic use of the internet and e-commerce: Cisco systems', The Journal of Strategic Information Systems, Vol. 11, No. 1, pp.5-29.

Le Masson, P.L., Weil, B. and Hatchuel, A. (2010) Strategic Management of Innovation and Design, Cambridge University Press, Cambridge; New York. 
Levy, M., Loebbecke, C. and Powell, P. (2003) 'SMEs, co-opetition and knowledge sharing: the role of information systems', European Journal of Information Systems, Vol. 12, No. 1, pp.3-17.

Maniak, R. and Midler, C. (2008) 'Shifting from co-development to co-innovation', International Journal of Automotive Technology and Management, Vol. 8, No. 4, pp.449-468.

March, J.G. and Simon, H. (1958) Organizations, Willey, New York.

Moore, J. (1993) 'Predators and prey: a new ecology of competition', Harvard Business Review, Vol. 71, No. 3, pp.75-86.

Nakhla, M. (2003) 'Information, coordination and contractual relations in firms', International Review of Law and Economics, Vol. 23, No. 1, pp.101-119.

Osborn, R.N. and Hagedoorn, J. (1997) 'The institutionalization and evolutionary dynamics of interorganizational alliances and networks', The Academy of Management Journal, Vol. 40, No. 2, pp.261-278.

Peng, M.W. and Shenkar, O. (2002) 'Joint venture dissolution as corporate divorce', The Academy of Management Executive (1993), Vol. 16, No. 2, pp.92-105.

Segrestin, B. (2005) 'Partnering to explore: the Renault-Nissan alliance as a forerunner of new cooperative patterns', Research Policy, Vol. 34, No. 5, pp.657-672.

Soh, P. (2009) 'Network patterns and competitive advantage before the emergence of a dominant design', Strategic Management Journal, Vol. 31, No. 4, pp.438-461.

Stieglitz, S. and Lattemann, C. (2008) 'Governance of Web 2.0 platforms in the stock exchanges industry', International Journal of Electronic Banking, Vol. 1, No. 1, pp.46-59.

Suh, N.P. (1990) The Principles of Design, Vol. 226, Oxford University Press, New York.

Teece, D.J. and Chesbrough, H.W. (2002) 'Organizing for innovation: when is virtual virtuous?', Harvard Business Review, Vol. 80, No. 1, pp.127-135.

von Hippel, E. (2010) 'Comment on 'Is open innovation a field of study or a communication barrier to theory development?', Technovation, Vol. 30, Nos. 11/12, pp.555-555.

von Krogh, G. (2011) 'Is open innovation a field of study or a communication barrier to theory development? A commentary', Technovation, Vol. 31, No. 7, pp.286-286.

Wenger, E. (2007) Communities of Practice: Learning, Meanings, and Identity, Cambridge University Press, New York.

West, J. and Lakhani, K.R. (2008) 'Getting clear about communities in open innovation', Industry \& Innovation, Vol. 15, No. 2, p.223.

Wiggins, A. and Crowston, K. (2010) 'Developing a conceptual model of virtual organisations for citizen science', International Journal of Organisational Design and Engineering, Vol. 1, No. 1, pp.148-162.

\section{Notes}

1 Netvibes UWA: Netvibes Universal Widget API. A platform launched by Netvibes web service as a design tool-kit for external developers.

2 Available at http://www.mashpit.pbwiki.com/MashPitParis (accessed on 11 January 2008). 